ABDI: Jurnal Pengabdian dan Pemberdayaan Masyarakat ISSN: 2656-369X (Print), 2684-8570 (Online)

Volume 3 No. 2, Desember 2021

http://abdi.ppj.unp.ac.id/index.php/abdi

Email: abdi@ppi.unp.ac.id

DOI: https://doi.org/10.24036/abdi.v3i2.125

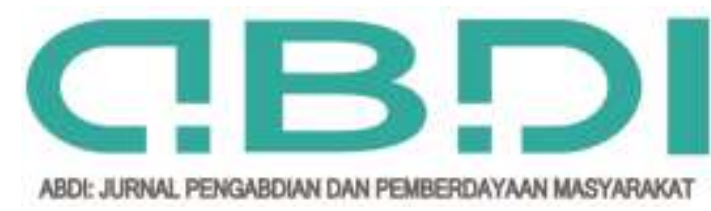

\title{
Pelatihan Desain Kemasan Produk Olahan Bandeng di Desa Sawohan Sidoarjo
}

\author{
Dyan Agustin
}

Program studi Arsitektur, Universitas Pembangunan Nasional Veteran Jawa Timur

E-mail: dyanagustin.ar@upnjatim.ac.id

\begin{abstract}
Abstrak
Desa Sawohan terletak di pesisir Sidoarjo dengan mata pencaharian sebagai petani tambak. Sekarang ini di Desa Sawohan banyak bermunculan industri kecil yang menghasilkan berbagai produk yang tidak kalah kwalitasnya salah satunya adalah UD. AABA yang menghasilkan antara lain produk bandeng presto, bandeng crispy, bandeng tanpa duri, kerupuk udang, kerupuk payus dll. Kesulitan yang dihadapi para pengrajin tersebut adalah karena kemasan dari produk mereka yang kurang menarik sehingga tidak bisa menembus pasar lebih besar. Dari permasalahan tersebut maka diperlukan solusi yaitu pelatihan desain kemasan dan pemasaran secara online. Saat ini kemasan bukan lagi sebagai pelindung atau wadah tetapi harus dapat menjual produk yang dikemasnya. Peningkatan pemasaran suatu produk dapat dilakukan melalui perbaikan desain kemasan. Desain kemasan yang baik adalah desain yang mampu memberikan informasi yang lengkap, menarik dan jelas dalam memasarkan suatu produk khususnya produk hasil tambak yang dihasilkan oleh masyarakat Desa Sawohan Sidoarjo. Kegiatan pelatihan dilaksanakan dengan melatih desain kemasan untuk meningkatkan kualitas produk. Desain kemasan bandeng dibuat semenarik mungkin dengan bentuk pillow box. Ada 3 jenis kemasan yang cocok digunakan pada produk olahan bandeng, antara lain kemasan primer yaitu kemasan plastic vacuum, kemasan sekunder yaitu kemasan kardus yang berbentuk kebab dan kemasan tersier yaitu berupa tas atau kardus. Dengan adanya kegiatan pengabdian ini menghasilkan desain kemasan yang baru, menarik dan aman dari produk hasil tambak di Desa Sawohan Sidoarjo sehingga produk mereka akan bisa menembus pasar yang lebih besar dan bisa menambah pendapatan serta menjadikan desa Sawohan lebih dikenal dan nantinya bisa menjadi desa wisata.
\end{abstract}

Kata kunci: Bandeng, Desain kemasan, Desa Sawohan, Tambak

\section{Abstract}

Sawohan village is located on the coast of Sidoarjo with a livelihood as a pond farmer. Currently in Sawohan Village, there are many small industries that produce various products that are not inferior in quality, one of which is UD. AABA which produces, among others, presto milkfish, crispy milkfish, thornless milkfish, prawn crackers, crackers, etc. The difficulties faced by these craftsmen are due to the unattractive packaging of their products so they cannot penetrate the larger market. From these problems, a solution is needed, namely packaging design training and online marketing. Currently, packaging is no longer a protector or a container but must be able to sell the product it packs. Increasing the marketing of a product can be done through improving the packaging design. A good packaging design is a design that is able to provide complete, interesting and clear information in marketing a product, especially pond products produced by the people of Sawohan Village, Sidoarjo.Training activities were carried out by training in packaging design to improve product quality. The design of the milkfish packaging is made as attractive as possible with a shape pillow box. There are 3 types of packaging that are suitable for use in processed milkfish products, including primary packaging, namely vacuum plastic packaging, secondary packaging, namely cardboard packaging in the form of kebabs and tertiary packaging in the form of bags or cardboard. With this service activity, they produce new, attractive and safe packaging designs from fishpond products in Sawohan Village, Sidoarjo so that their products will be able to penetrate a larger market and can increase income and make Sawohan village better known and later can become a tourist village.

Key Word: Milkfish, Packaging design, Sawohan Village, Pond

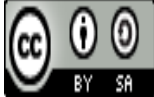




\section{Pendahuluan}

Kabupaten Sidoarjo dikenal dengan sebutan Kota Delta dan merupakan kabupaten yang berbatasan dengan kota Surabaya. Letaknya berada di antara dua sungai besar pecahan Kali Brantas, yakni Kali Mas dan Kali Porong dengan sektor perekonomian utama perikanan, industri dan jasa. Di sektor perikanan, Kabupaten Sidoarjo mengandalkan udang dan bandeng sebagai komoditas unggulan yang merupakan maskot Kabupaten Sidoarjo. Kontribusi subsektor perikanan $(49,7 \%)$ terhadap PDRB Kabupaten Sidoarjo lebih tinggi dibandingkan subsektor pertanian lainnya. Kabupaten Sidoarjo identik dengan tambak (15.530 hektar).(Barokah, 2011). Banyak sentra industri olahan hasil tambak terutama di Desa Sawohan dikarenakan berlimpahnya jumlah komoditi serta rasa yang enak dari olahan hasil tambak tersebut

Desa Sawohan adalah sebuah desa yang penduduknya bermata pencaharian sebagai petani tambak. Menurut data yang didapat bahwa mata pencaharian utama penduduk Desa Sawohan adalah petani tambak (Saktiati, Zainudin, \& Dkk, 2019) . Di desa tersebut juga di lahirkan tokoh tokoh besar dari Sidoarjo antara lain bupati sidoarjo drs.H Syaiful illah, bapak H. Achmad rifa'i yang merupakan perwira tinggi marinir, makam ibu dari Sunan Giri yaitu Raden Ayu Dewi Sekardadu atau Mbah Buyut. Sehingga sebenarnya desa Sawohan bisa dikembangkan menjadi salah satu Desa Wisata di Sidoarjo.
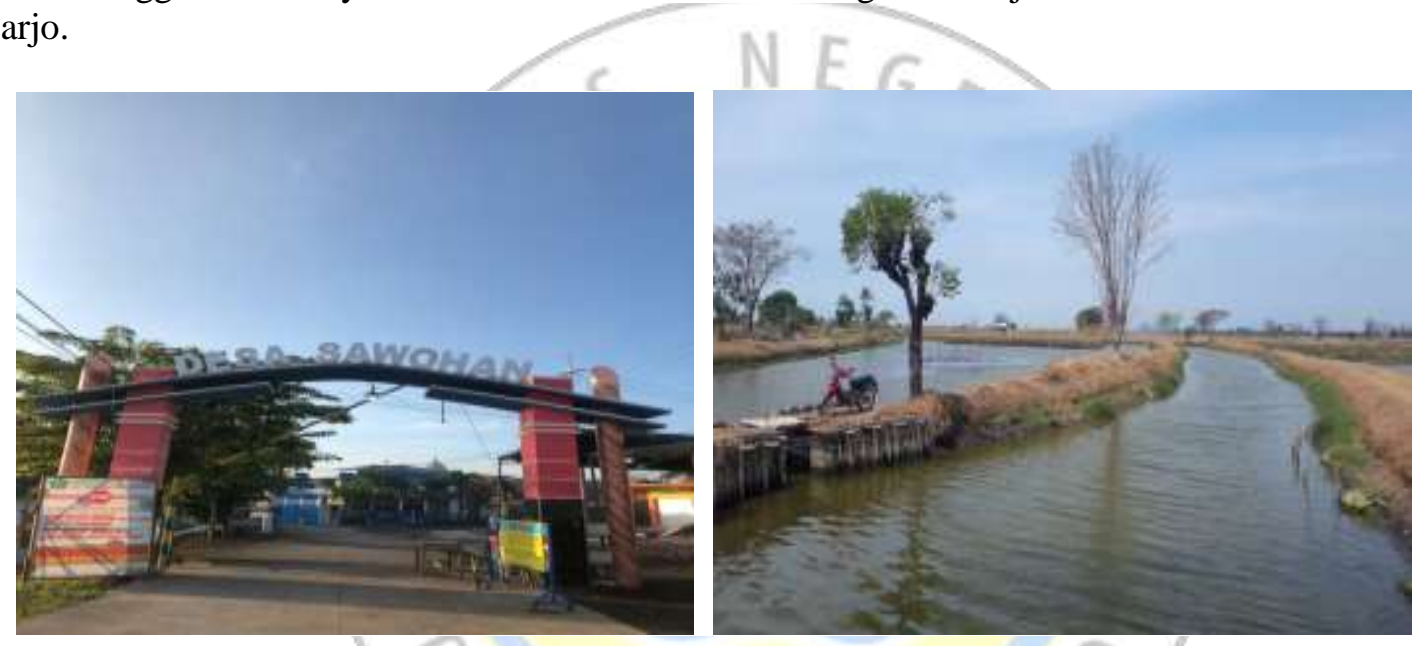

\section{Gambar 1. Gerbang dan suasana tambak Desa Sawohan Sidoarjo}

Pengembangan industri pengolahan saat ini masih terbatas di lingkup pasar lokal karena teknologi yang masih sederhana serta pengemasan produk yang kurang menarik. Mereka belum bisa menembus persaingan pasar yang lebih luas misalnya dengan menitipkan di pusat oleh oleh bahkan dalam skala lebih besar menarik konsumen kedaerah Sawohan untuk berbelanja produk hasil tambak karena kemasan yang kurang menarik belum bisa menarik perhatian konsumen. Salah satu usaha yang dapat dilakukan untuk menghadapi persaingan yang semakin tajam adalah dengan desain kemasan. Daya tarik suatu produk tidak dapat terlepas dari kemasannya (Yunita, Bramantijo, \& Sutanto, 2013). Kemasan merupakan faktor penarik karena ia langsung berhadapan dengan konsumen. Karena itu kemasan harus dapat mempengaruhi konsumen untuk memberikan respon positif, dalam hal ini membeli produk; karena tujuan akhir dari pengemasan adalah untuk menciptakan penjualan (Naufalin \& Sustriawan 2013).

Kemasan adalah salah satu bidang dalam Desain Komunikasi Visual yang mempunyai banyak tuntutan khusus antara lain dari segi kreatifitas, teknis dan komunikatif karena fungsinya yang langsung berhadapan dengan konsumen (Clara, 2021). Proses pelatihan dilakukan oleh tim dosen program studi Arsitektur dan Desain Komunikasi Visual (DKV) Fakultas Arsitektur dan Desain UPN Veteran Jawa Timur. Berdasarkan kepakaran dari pengusul yang mengampu mata kuliah kewirausahaan dimana salah satu bab nya yaitu cara branding produk melalui desain kemasan serta cara pemasaran produk. Disamping itu juga pada tahun 2017 juga telah mengadakan pelatihan desain kemasan olahan hasil tambak di Desa Tambak Oso Sidoarjo (Agustin \& Widyasari, 2018). 
Pendampingan pelatihan dilaksanakan selama kurang lebih 2 minggu dengan jumlah peserta 8 orang pemilik dan karyawan UD. AABA.

Perkembangan home industri secara tidak langsung akan bisa meningkatkan perekonomian rumah tangga. Usaha Mikro, Kecil, dan Menengah juga mampu bertahan pada masa krisis ekonomi nasional. UMKM bahkan mampu menyediakan lapangan pekerjaan, barang-barang murah, dan melahirkan wirausaha-wirausaha baru. Perkembangan UMKM mengalami beberapa masalah salah satunya adalah masalah pemasaran khususnya terkait branding (Sudarwati \& Eka Satya, 2013).

Sekarang ini banyak bermunculan industri kecil yang menghasilkan berbagai produk yang tidak kalah kwalitas nya salah satunya industri hasil tambak di Desa Sawohan Sidoarjo. Menurut hasil wawancara bahwa saat ini terdapat kurang lebih 10 pengrajin produk hasil tambak di Desa Sawohan Sidoarjo dan salah satunya UD. AABA yang merupakan salah satu pengrajin yang sudah berdiri lama dan menghasilkan antara lain produk bandeng presto, bandeng crispy, bandeng tanpa duri, kerupuk udang, kerupuk payus dll.
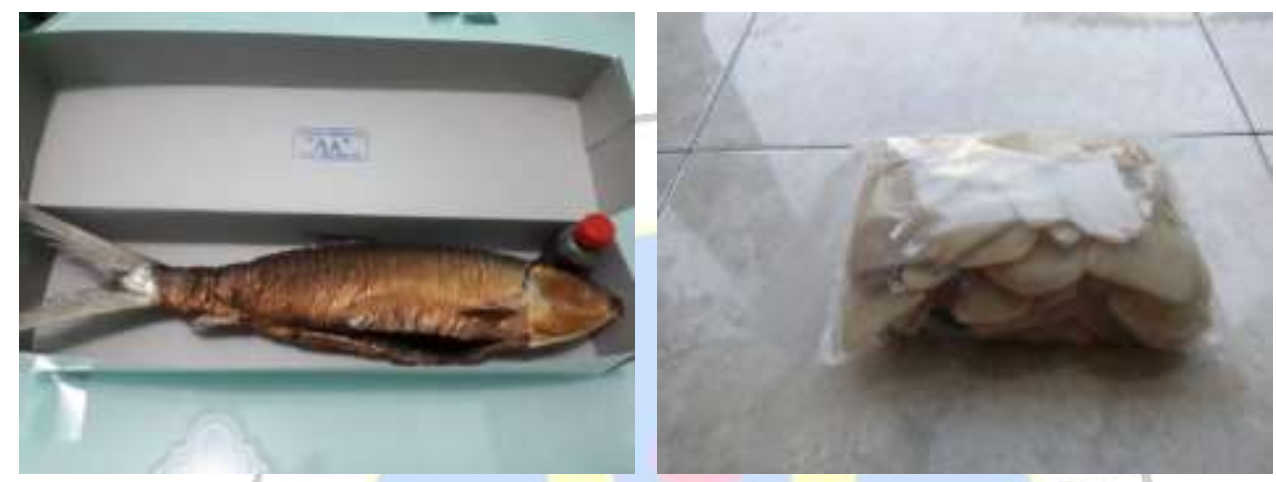

\section{Gambar 2. Contoh produk bandeng dengan kemasan kerdus warna putih oleh UD AABA}

Dari hasil pengamatan dan wawancara dengan beberapa pengrajin tersebut didapatkan data bahwa mereka kesulitan menjual produk mereka padahal rasa dari produk mereka cukup bisa bersaing dengan lainnya. Kesulitan tersebut adalah karena kemasan dari produk mereka yang kurang menarik sehingga tidak bisa menembus pasar lebih besar. Kemasan produk merupakan salah satu unsur penting yang mempengaruhi banyaknya permintaan konsumen dan banyaknya penjualan terhadap produk (Prasetyowati, Rasiman, Minarti, \& Setiawan, 2020). Hal ini yang menjadikan latar belakang diajukannya program ini yaitu pelatihan desain kemasan produk hasil tambak di Desa Sawohan Sidoarjo. Dari program ini diharapkan para pengrajin penghasil produk hasil tambak di Desa Sawohan dapat termotivasi untuk menghasilkan kemasan yang menarik sehingga bisa meningkatkan nilai jual yang pada akhirnya bisa menambah sumber penghasilan mereka.

Dengan pelatihan desain kemasan maka akan dapat memberikan pengetahuan kepada mitra mengenai alternatif kemasan yang dapat dipilih untuk menampilkan produk yang lebih baik di pasaran dan pemberian label dapat membantu memberikan informasi kepada konsumen (Fitriani et al., 2020). Tujuan dari program ini adalah menumbuhkan kreatifitas dan ketrampilan dalam mendesain berbagai hasil produk mereka sehingga lebih bisa bersaing dalam penjualan. Dengan kemasan baru tersebut maka harga jual dari produk olahan bandeng mereka akan lebih meningkat.

\section{Metode Pelaksanaan}

Metode pelaksanaan program pengabdian ini berupa pelatihan-pelatihan, pembinaan, pendampingan dan pemberian ketrampilan kepada UMKM Desa Sawohan untuk mengembangkan pemasaran dan potensi hasil olahan tambak yang dimiliki, sehingga bisa meningkatkan kesejahteraan masyarakat. Pelatihan dapat memberikan pengetahuan kepada mitra mengenai alternatif kemasan yang dapat dipilih untuk menampilkan produk yang lebih baik di pasaran dan pemberian label dapat membantu memberikan informasi kepada konsumen (Fitriani et al., 2020). 
Tahapan pelaksanaan program pengabdian ini antara lain:

a. Tahap Penyuluhan

Pada tahap ini dijelaskan tentang pentingnya peranan desain kemasan untuk dapat meningkatkan penjualan dan brand produk.

b. Tahap Pelatihan

Pada tahap ini dilakukan pelatihan dan pendampingan tentang desain kemasan untuk meningkatkan brand serta pelatihan cabut duri untuk peningkatan kualitas produk. Untuk proses pembelajaran desain dan percetakannya saat ini masih didampingi tim pelatih. Karena saat ini belum ada yang bisa mengoperasikan program corel. Tetapi untuk kedepannya mereka akan merekrut tim khusus yang lebih mengenal desain.

Sedangkan untuk khalayak sasaran adalah beberapa UMKM olahan hasil tambah di Desa Sawohan salah satunya UMKM AABA. UMKM AABA ini sudah menghasilkan produk antara lain bandeng asap, bandeng dendeng, bandeng bakar bumbu kecap, bandeng presto, bandeng otak otak, bandeng goreng, udang bakar, kerupuk ikan.

\section{Hasil dan Pembahasan}

Kegiatan ini merupakan kegiatan pemberdayaan UMKM khususnya UMKM AABA di Desa Sawohan Sidoarjo yang bertujuan untuk membangkitkan potensi UMKM Desa Sawohan. Hal ini dikaitkan juga dengan permasalahan dari desa Sawohan yang kemasan produk olahan bandengnya masih belum bagus. Tahapan yang dilakukan dalam kegiatan ini adalah penyuluhan dan pelatihan. Pada saat penyuluhan dan pelatihan peserta yang terdiri dari ibu ibu UMKM ini sangat antusias dan menyimak serta berinteraksi aktif. Pada saat pelatihan jumlah peserta dibatasi dan diharuskan sesuai dengan protokol kesehatan karena pelaksanaannya dimasa pandemic agar tetap bisa menjaga jarak

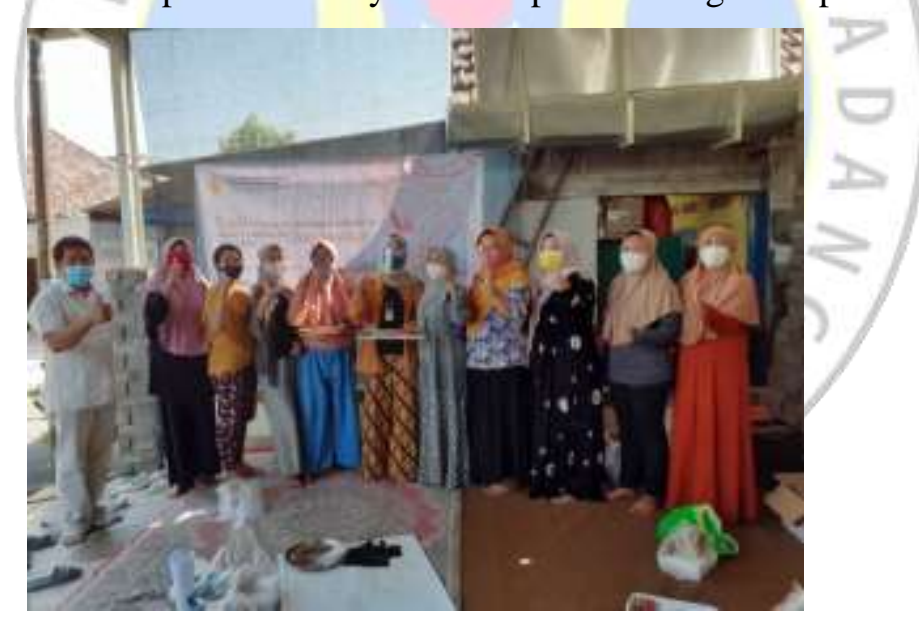

\section{Gambar 3. Peserta Kegiatan Pelatihan Desain Kemasan Desa Sawohan Sidoarjo}

Pada saat pelatihan mereka diberi pendampingan secara intensif tentang membangun branding, meredesain kemasan bagi yang sudah mempunyai kemasan serta mendesain baru bagi yang belum mempunyai kemasan. Beberapa UMKM yang ada antara lain UMKM Bandeng olahan.

Melalui kegiatan pengabdian ini di sarankan untuk merebranding AABA dengan membuat merek baru yang lebih mengarah ke segmen anak muda serta lebih mudah diingat. Akhirnya setelah digali dalam konsep yang mendalam didapatkan nama brand Mr. BAND yang merupakan kepanjangan dari BANDeng. Program redesain kemasan dan brand ini adalah dengan maksud untuk menampilkan kekuatan dari brand baru. 


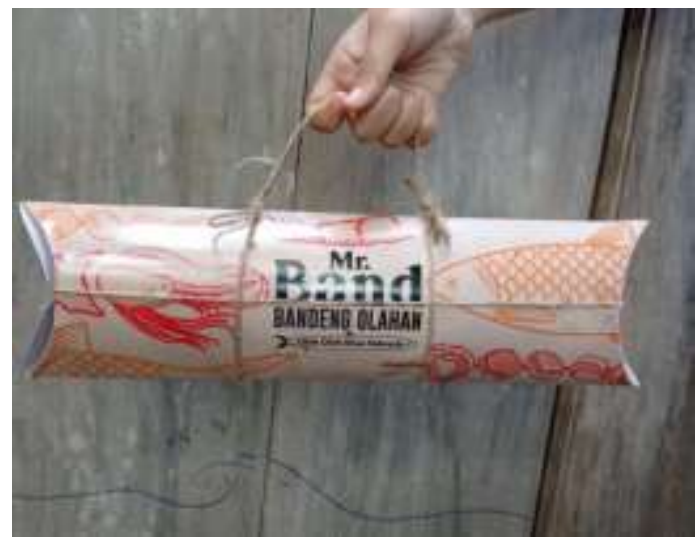

\section{Gambar 4. Kemasan Kemasan Baru Produk Olahan Bandeng Desa Sawohan Sidoarjo}

Untuk keberlanjutan dari pelaksanaan desain dan percetakan ini CV AABA dalam jangka panjang akan merekrut SDM yang mengerti tentang desain untuk lebih memperkuat branding produk seiring penngkatan penjualan. Sedangkan saat ini mereka masih dalam pendampingan tim pelatih sampai ke percetakan. Sedangkan biaya yang di butuhkan untuk percetakan bisa di sediakan oleh CV AABA dikarenakan memang kemasan yang lama sudah akan habis. Untuk saat ini belum diadakan kerjasama dengan percetakan karena masih dalam tahap percobaan dan melihat respon pasar. Untuk harga satuan kemasan masih terjangkau oleh pengusaha bandeng dengan perkiraan harga 5.600 per kemasan. Sedangkan rencana harga jual produk bandeng re branding ini adalah sekitar 75.000125.000 karena rebrandingnya sekaligus pada produknya yaitu khusus di bandeng yang besar, sehingga juga akan mengangkat harga jual serta focus pada produk oleh-oleh.

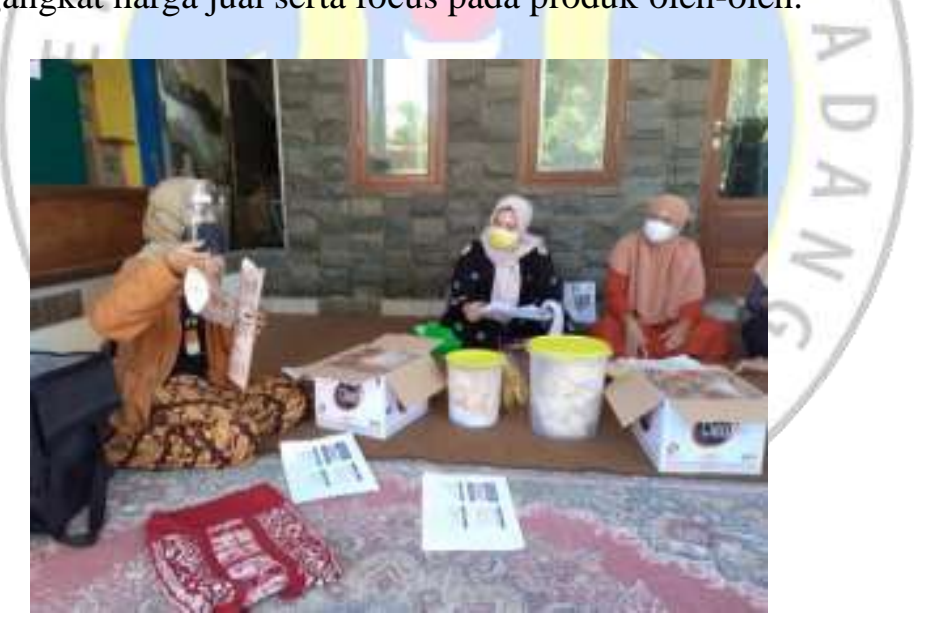

\section{Gambar 5. Suasana Pelatihan Desain Kemasan Desa Sawohan Sidoarjo}

Variabel desain kemasan terdiri dari 3 dimensi, antara lain desain grafis, struktur desain, dan informasi produk ( Nilsson \& Ostrom dalam Cahyorini \& Rusfian, 2012):

a. Desain Grafis adalah tampilan visual pada permukaan kemasan dan terdiri dari empat sub dimensi, antara lain nama merek, warna, tipografi, serta gambar.

b. Struktur Desain yaitu hal yang berkaitan dengan fitur-fitur fisik kemasan, antara lain bentuk, ukuran, dan material.

c. Informasi Produk yang berfungsi untuk mengkomunikasikan produk melalui informasi yang tertera dalam desain kemasan. Informasi produk dapat membantu konsumen dalam membuat keputusan pembelian dengan lebih hati-hati (Silayoi \& Speece, 2007).

Dimensi dari kemasan memiliki peran masing-masing untuk menghasilkan kemasan yang baik dan menarik, karena semakin menarik kemasan tersebut semakin menarik perhatian para konsumen. 


\subsection{Konsep Logo}

Elemen identitas visual brand yang utama salah satunya adalah logo dengan fungsi dasar identifikasi dan diferensiasi. Logo secara langsung akan mengidentifikasi dengan brand dan menjadi kekuatan logo (Hardy, 2011). Logo yang digunakan pada brand Mr. BAND ini adalah gambar kartun dari ikan bandeng yang memakai dasi. Maksud dari pemakaian gambar bandeng ini agar bisa menginformasikan kalau isi produk dalah produk olahan bandeng. Sedangkan gambar dasi dimaksudkan adalah bahwa produk ini tidak hanya bisa dikonsumsi rumah tangga tetapi juga bisa digunakan untuk oleh oleh, atau mungkin hantaran untuk relasi bisnis dan lebih mengarah ke pangsa anak muda dan eksekutif muda.

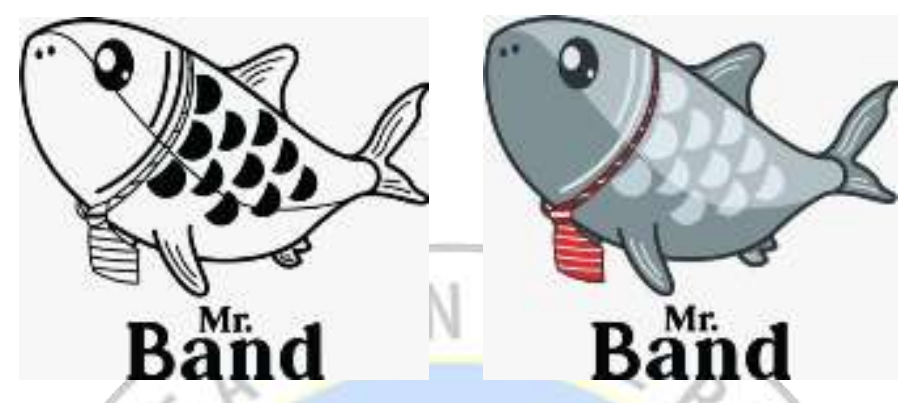

Gambar 6. Logo baru rebranding UMKM AABA

\subsection{Bentuk Kemasan}

Kemasan pada olahan bandeng terdiri dari 3 jenis:

\subsubsection{Kemasan primer (primary pack)}

Berupa kemasan plastik yang di vakum dengan maksud agar lebih higienis serta lebih tahan lama. Metode pengemasan vakum merupakan metode kemasan dengan menghilangkan udara atau oksigen dengan menggunakan plastik khusus. Hal ini dimaksudkan agar pada saat oksigen dikeluarkan maka akan membatasi pertumbuhan bakteri aerobic dan tidak akan mudah basi sehingga akan memperpanjang waktu kadaluarsa (Purnamayati, Wijayanti, Dwi Anggo, Amalia, \& Sumardianto, 2018). Jenis plastik yang digunakan adalah jenis nylon. Plastik nylon mempunyai tingkat elastisitas dan daya kerat yang kuat sehingga tidak mudah bocor. Dengan penggunaan plastic vakum ini maka produk olahan bandeng akan lebih awet, health, higienis dan akan menambah daya tarik dan keunggulan produk. Selain itu dengan produk yang bisa lebih tahan lama maka akan dapat menekan kerugian akibat produk yang tidak laku terjual.

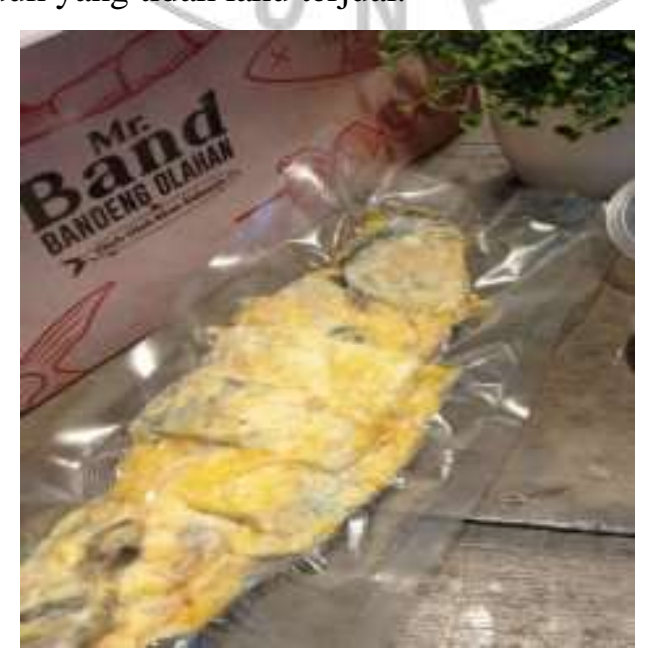

Gambar 7. Kemasan primer ( primary pack) 


\subsubsection{Kemasan Sekunder (secondary pack)}

Pola dasar single pack untuk kemasan olahan bandeng pada umumnya adalah berbentuk segi empat. Keunggulan dari bentuk ini memang lebih mudah dan nyaman untuk dipacking. Akan tetapi bentuk ini sudah banyak digunakan dan tidak mempunyai keunikan. Untuk itu digunakan konsep baru dengan bentuk pillow box yang memiliki bentuk unik dan berbeda dari kemasan pada umumnya serta ergonomis sesuai dengan bentuk bandeng itu sendiri. Selain itu juga kemasan ini bertujuan untuk menjadikan cirikhas dari produk kami dan agar menjadi daya tarik orang yang ingin membelinya.

Dalam kemasan ini tidak hanya dikemas untuk produk makanan bandeng saja, namun juga menu produk makanan lainnya seperti udang dan kerang. Tujuan menggabungkan jenis menu dalam 1 kemasan yang sama agar lebih efisien. Pada tampilan kemasan memiliki 2 sisi yaitu atas dan bawah. Kemasan atas berisi judul kemasan beserta ilustrasi ikan yang dijual dan untuk kemasan yang bawah berisi informasi mengenai produk makanan, dan terdapat lubang pada bagian sisik ikan di tengah agar pembeli bisa melihat produk di dalamnya. Bahan pada kemasan ini memakai jenis kertas craft paper, karena kertas tersebut memiliki warna coklat dan sedikit tebal.

Sedangkan untuk pembelian satuan disediakan tali untuk memudahkan pembeli membawa produk bandeng nya. Tali ini berbahan goni yang cukup kuat dengan penampilan unik dan menarik

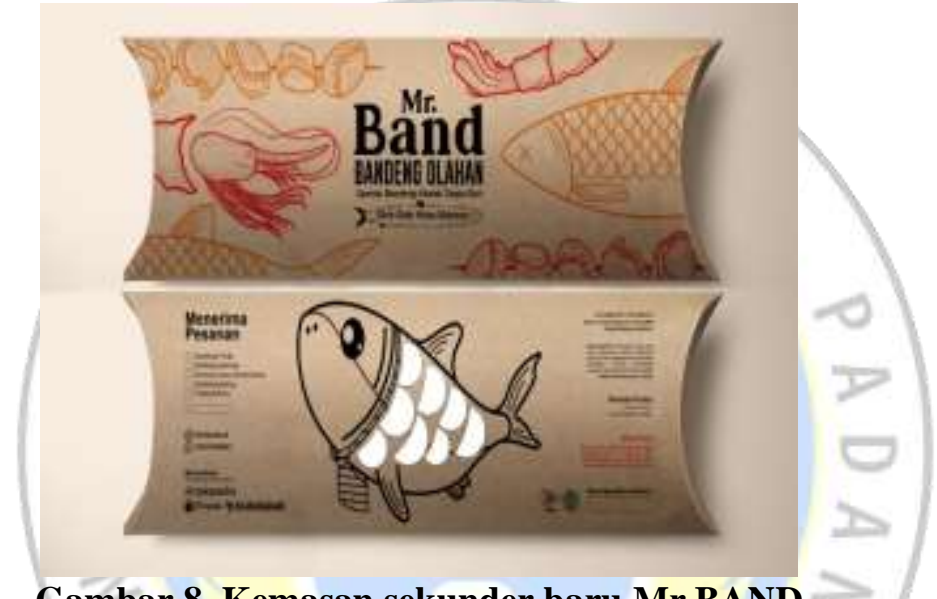

\section{Gambar 8. Kemasan sekunder baru Mr.BAND}

Dari segi desain pada kemasan ini menampilkan ilustrasi ikan, udang dan sate kerang. Penggunakan ilustrasi tersebut di sesuaikan dengan produk yang akan di jual nantinya, selain itu juga agar masyarakat tahu bahwa produk ini tidak hanya menjual olahan bandeng saja tetapi juga menjual beberapa olahan lainnya. Untuk warna yang dipakai pada kemasan ini menggunakan warna merah, kuning, dan juga orange. Warna tersebut memiliki arti semangat, ceria, dan energik seperti yang ada pada para petani tambak desa sawohan. Dan diharapkan juga semakin banyak masyarakat membeli produk ini akan menambah semangat dan keceriaan masyarakat desa sawohan. Selain itu juga warna tersebut tergolong warna cerah yang dapat menarik mata konsumen untuk melihatnya. Warna merah termasuk ke dalam gelombang elektromagnetik terpanjang dan dapat dengan cepat ditangkap oleh mata. Warna membawa makna intrinsik yang menjadi pusat identitas brand, berkontribusi terhadap pengenalan brand (Abril, Olazábal, \& Cava, 2009). Warna merah mengarah pada kinerja yang lebih baik pada tugas yang berorientasi pada detail (Mehta \& Zhu, 2009). Kemudian warna coklat yang dijadikan warna utama pada kemasan adalah ingin menampilkan kesan klasik natural dan dipadukan kedalam desain modern pada kemasan. Warna coklat juga menggambarkan warna tanah yang merepresentasikan tempat pembudidayaan bandeng di tambak

\subsubsection{Kemasan Tersier (tertiary pack)}

Kemasan tertiary pack digunakan sebagai media penunjang dari kemasan sekunder. Ada beberapa jenis kemasan tertiary pack yang digunakan antara lain:

- Kemasan tersier isi maksimal 3 
Kemasan ini dibuat untuk apabila pelanggan yang membeli dalam jumlah sedikit dan agar mudah membawa produk bandeng, ditujukan untuk menampung 1 sampai 3 kemasan sekunder. Kemasanini menggunakan material craf paper ukuran tebal. Dari segi desain sama seperti kemasan utama bandeng, yang bertujuan untuk menyelaraskan kemasan. Ada 3 desain yang dihasilkan pada kemasan tersier isi maksimal 3 ini, antara lain bentuk tas, box terbuka dan box tertutup.
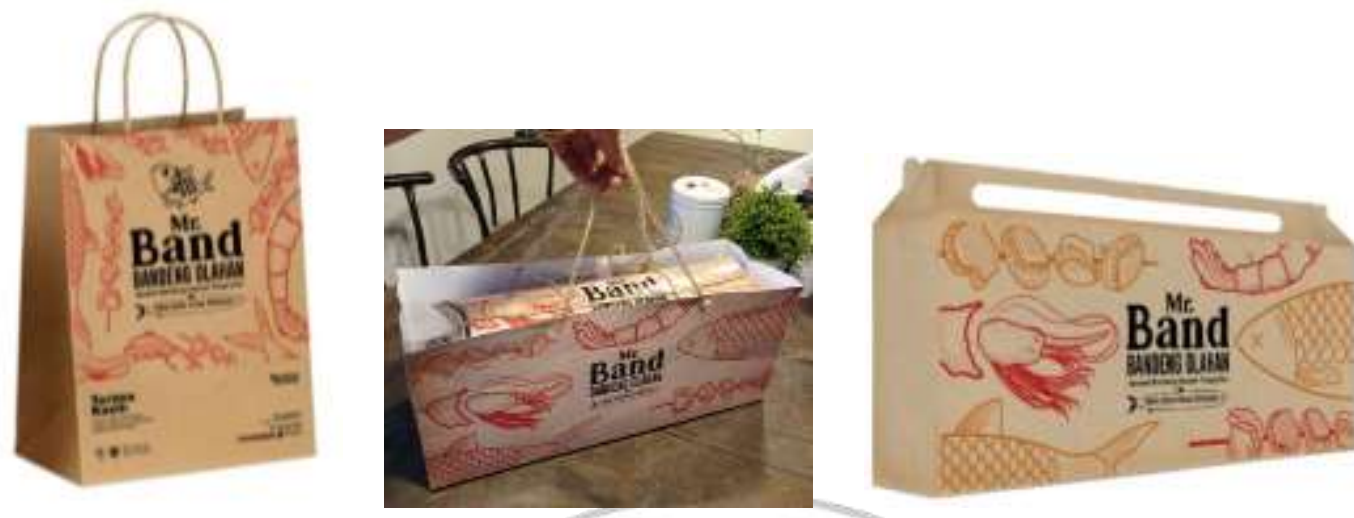

Gambar 9. Kemasan tersier isi 3

Kemasan karton dapat menampung maksimal 7 secondary pack. Kemasan ini dibuat khusus untuk didistribusikan atau dibawa bepergian hingga ke luar kota atau luar pulau, oleh karena itu kemasan ini dibuat dari kardus yang cukup tebal dan lebih tahan terhadap tekanan.

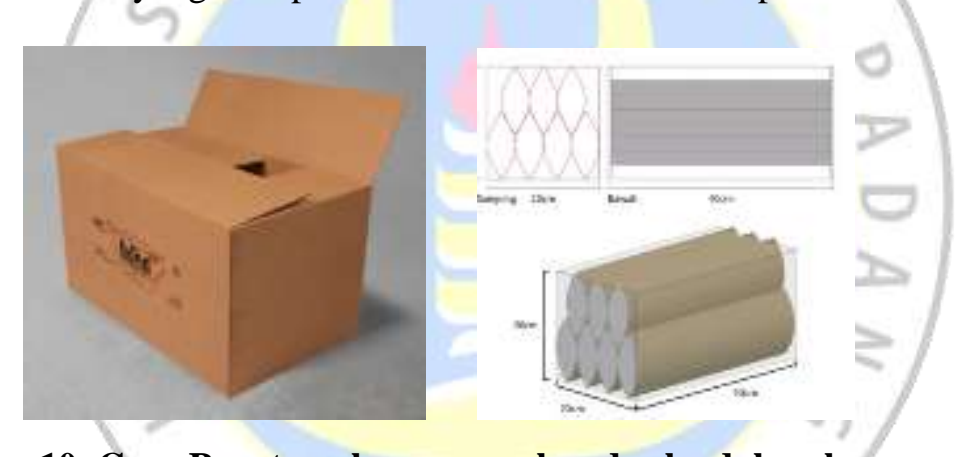

\section{Gambar 10. Cara Penataan kemasan sekunder ke dalam kemasan tersier}

\section{Kesimpulan}

Untuk dapat meningkatkan kualitas suatu produk bisa melakukan langkah rebranding dan desain kemasan. Pada produk hasil tambak diperlukan konsep yang mencerminkan produk nya yaitu ikan, tambak, alami. Pada UKM olahan bandeng di Desa Sawohan mengalami kendala dan belum maksimal dalam hal kemasan dan logo. Untuk itu diperlukan pendampingan dan pelatihan desain kemasan produk olahan bandengnya sekaligus rebranding agar lebih meningkatkan nilai dari produk olahan bandeng Desa Sawohan. Untuk logo digunakan ikan yang paling menjadi unggulan yaitu ikan bandeng. Sedangkan untuk bentuk kemasan ada tiga jenis antara lain kemasan primer yaitu kemasan yang langsung berhubungan dengan produk bandeng, berbahan plastik dan kedap udara atau vakum. Hal ini dimaksudkan agar higienis dan lebih tahan lama. Jenis kedua adalah kemasan sekunder, yaitu kemasan yang mewadahi kemasan primer, yang menunjukkan karakter dan brand dari produk. Bentuk yang dipilih adalah pillow box dengan maksud agar mudah dibawa, unik, menarik, mudah diingat dan sesuai dengan bentuk ergonomis dari bandeng itu sendiri. Sedangkan jenis yang ketiga adalah kemasan tersier yaitu berfungsi mewadahi beberapa kemasan pillow box. Kemasan ini disiapkan apabila ada yang membeli produk lebih dari satu. Disiapkan desain kemasan tersier dalam beberapa bentuk yaitu isi 3 dan isi 7 . 
Konsep warna dipilih warna coklat untuk menyimbolkan warna tanah di tambak. Bahan yang digunakan untuk kemasan hasil tambak di pilih bahan yang tahan lama, kuat dan menarik agar bisa menarik perhatian sehingga bisa meningkatkan penjualan terutama di Desa Sawohan Sidoarjo. Karakteristik produk olahan bandeng terkait dengan kemasan adalah produk lunak, mudah basi sehingga diperlukan kemasan yang kaku, kedap udara, dan tidak tembus minyak.

\section{Daftar Pustaka}

Abril, P. S., Olazábal, A., \& Cava, A. (2009). Marketing and the Law. Journal of the Academy of Marketing Science, 37, 375-380.

Agustin, D., \& Widyasari. (2018). Packaging Design of Milkfish Products in Tambak Oso Village Sidoarjo. 2(2), 151-159. https://doi.org/10.11594/nstp.2018.0122

Barokah, U. (2011). Strategi Pengembangan Perikanan Tambak Sebagai Sub Sektor Unggulan Di Kabupaten Sidoarjo. Seminar Nasional Competitive Advantage 2011, 1(1), 1-5.

Cahyorini, A., \& Rusfian, E. Z. (2012). The Effect of Packaging Design on Impulsive Buying. Journal of Administrative Science \& Organization, 18(1), 11-21.

Clara, C. (2021). Pengaruh Desain Dan Manfaat Kemasan Terhadap Minat Pembelian FMCG. Jurnal Keuangan dan Bisnis, 19(1), 1-10.

Fitriani, E., Fatimah, S., Mardiah, D., Selinaswati, S., Hidayat, M., \& Amelia, L. (2020). Pengemasan (Packaging) Rakik Bada Lado Hijau Upaya Peningkatan Pemasaran dan Pelestarian Kuliner Minangkabau. Abdi: Jurnal Pengabdian dan Pemberdayaan Masyarakat, 2(2), 130-135. https://doi.org/10.24036/abdi.v2i2.59

Hardy, G. (2011). Smashing Logo Design: The Art of Creating Visual Identities 1st Edition. Wiley; 1st edition (June 15, 2011).

Mehta, R., \& Zhu, R. (2009). Blue or Red? Exploring the Effect of Color on Cognitive Task Performances. Science, 323(5918), 1226-1229. Retrieved from https://science.sciencemag.org/content/323/5918/1226

Naufalin, R., \& Sustriawan, B (2013). D. esain Bentuk Dan Kemasan Untuk Mempertahankan Mutu Gula Kelapa Mold Design and Packaging to Maintain Palm Sugar Quality, Pembangunan Pedesaan, 13(1), 2

Prasetyowati, D., Rasiman, R., Minarti, I. B., \& Setiawan, D. F. (2020). Peningkatan Kualitas dan Kemasan pada Kelompok Usaha Kerupuk Ikan di Desa Bendar Kecamatan Juwana Kabupaten Pati. Abdi: Jurnal Pengabdian dan Pemberdayaan Masyarakat, 2(2), 110-119. https://doi.org/10.24036/abdi.v2i2.68

Purnamayati, L., Wijayanti, I., Dwi Anggo, A., Amalia, U., \& Sumardianto, S. (2018). Pengaruh Pengemasan Vakum Terhadap Kualitas Bandeng Presto Selama Penyimpanan. Jurnal Teknologi Hasil Pertanian, 11(2), 63. https://doi.org/10.20961/jthp.v11i2.29052

Saktiati, Zainudin, A., \& Dkk. (2019). Bertani di Ujung Negeri. Angewandte Chemie International Edition, 6(11), 951-952.

Silayoi, P., \& Speece, M. (2007). The importance of packaging attributes: a conjoint analysis approach. European Journal of Marketing, 4l(11), 1495-1517. https://doi.org/https://doi.org/10.1108/03090560710821279

Sudarwati, Y., \& Eka Satya, V. (2013). Strategi Pengembangan Merek Usaha Mikro, Kecil, dan Menengah. Jurnal Ekonomi \& Kebijakan Publik, 4(1), 89-101.

Yunita, C., Bramantijo, B., \& Sutanto, R. P. (2013). Redesain Kemasan Otak-otak Bandeng Bu Muzanah Khas Gresik. Jurnal DKV Adiwarna, 1(2), 11-21. 